\title{
Ciberespaço e bullying em uma obra de ficção contemporânea
}

Resumo: Este texto apresenta uma resenha da obra literária By the time you read this, I'll be dead (em livre tradução, Quando você ler isso, estarei morta), da autora Julie Anne Petters. A obra foi publicada pela editora Hyperion no ano de 2010, e contém 200 páginas, sendo que o livro ainda não possui tradução para a língua portuguesa. A resenha que se apresenta inclui descrição comentada do enredo da obra e observações críticas sobre a relevância do romance para seu público alvo, o qual incui tanto jovens inseridos no mundo digital e vítimas de práticas de bullying por motivos variados, quanto pais de adolescentes nestas condições.

Palavras-chave: Resenha literária. Julie Anne Petters. Bullying. Mundo digital.

Abstract: This text presents a review of the work By the time you read this, I'll be dead (in free translation, Quando você ler isso, estarei morta), by author Julie Anne Petters. The work was published by Hyperion in 2010, and it contains 200 pages and has not yet been translated to Portuguese. The following review includes a commented description of the work's plot and critical observations about the relevance of the novel to its target audience, which includes young people inserted in the digital world and victim of bullying practices for various reasons, and also the parents of teenagers in such conditions.

Keywords: Literary review. Jullie Anne Petters. Bullying. Digital world.

O que leva uma pessoa a decidir pelo suicídio? Como o bullying pode afetar a vida de alguém vítima de tal agressão? Até que ponto o ciberespaço pode influenciar possíveis ações de conotação negativa por parte deste sujeito? Estas e outras perguntas são recorrentes no mundo em que vivemos hoje, repleto de padrões de felicidade e beleza aparentemente acessíveis, porém ao mesmo tempo herméticos em seu rigor, excludente daqueles que não parecem "se encaixar". Neste mesmo mundo, o acesso a informação tornou-se relevante para todo e qualquer tipo de situação, e circulam mais livremente tanto as mensagems de padrões e ideologias clássicos quanto os engajamentos por maior aceitação do sujeito, em seus diversos níveis - estético, de raça, de orientação sexual, etnia, etc. Pensando nisso, Julie Anne Peters em seu livro By the time you read this, I'll be dead, voltando-o para o público infanto-juvenil, discute sobre bullying e suicídio em forma de ficção contando a história de Daelyn Rice, uma

\footnotetext{
1 Graduanda em Letras Inglês pela Universidade Federal do Pará (UFPA). E-mail: beatriz07desouza03@gmail.com

${ }^{2}$ Doutora em Letras - Literatura Inglesa (UFSC). Professora da Universidade Federal do Pará (UFPA). E-mail: sanfelici@ufpa.br
} 
garota de 15 anos que, por ter estado supostamente acima do peso, sofre bullying, e após tentativas de suicídio em vão, encontra no ciberespaço um site que orienta usuários a realizar com sucesso esse desejo pela morte, em um prazo de 23 dias. Envolvente e inusitada, a obra pautua temáticas importantes de uma forma que enreda o leitor em uma leitura fácil e ao mesmo tempo imbuída de complexidade.

Motivada por vários acontecimentos trágicos em sua vida, e um imenso histórico de bullying escolar, na vida social e até mesmo em um acampamento para perda de peso, a protagonista da história não consegue se estabelecer socialmente, não consegue confiar nas pessoas, nem mesmo em seus próprios pais, e assim se torna uma pessoa triste, deprimida, sentindo-se uma perdedora e indigna de viver, pois sente que sua vida não tem significado ou significância. Vendo-se sem motivos para viver, tenta suicidar-se cortando suas veias ou ingerindo produtos tóxicos, e como não consegue sente-se ainda mais inútil. Dados estes acontecimentos, a personagem passa por vários psicólogos, toma remédios antidepressivos e o tempo inteiro é vigiada por seus pais, que evitam deixá-la só e rastreiam por um computador tudo o que ela faz na internet, restringindo o seu acesso ao ciberespaço.

Apesar da restrição ao uso do computador, Daelyn consegue encontrar um site na internet chamado through-the-light (em português, "através da luz"), que alega não deixar rastros no histórico de navegação. Mesmo não confiando nisso (pois ela não confia em nada e em ninguém), ela acessa e abre uma conta para si e recebe um nome de usuário, pois na página ninguém pode ser conhecido pelo nome como forma de preservação da identidade. A partir da abertura da conta na página, é estipulado a ela um prazo para a efetivação da morte, que é de 23 dias, precisamente, dando-lhe um DOD (Day Of Determination, em português, "dia da determinação").

Diferente de outras páginas de ajuda ao suicida, esta deixa claro que apenas podem se inscrever nela quem realmente está decido a morrer, e não permite que links de auto-ajuda ou religiosos fiquem disponíveis. Também é advertido que, se algum usuário desestimular outros sobre a decisão, o mesmo será rastreado e automaticamente excluído da página, e nunca mais poderá ser reabilitado. No site existem diversos artifícios que referendam e estimulam a morte, como um fórum de discussão dividido por temas como intimidação, divórcio, ódio à vida, desânimo, violência, entre outros. Há ainda um link nomeado WTG (Way To Go, em português, "maneiras de ir”), que como o nome já diz trata-se de um espaço com vários tipos de suicídio descritivos por níveis de 0 à 5 de intensidade de dor e eficácia, e explicação detalhada de como fazer ou encontrar os materiais necessários para a realização, além de 
outras informações relacionadas. Ao passar dos dias seriam feitas algumas perguntas obrigatórias ao usuário, como por exemplo: como seria a morte, quem deixaria para traz, qual o motivo, se havia escolha, e ainda era necessário deixar uma espécie de depoimento para aqueles que ficassem.

Ao longo dos dias que se passam Daelyn começa a fazer amizade com uma garota do coral e com um rapaz morador próximo da escola, que todos os dias a encontra depois da aula, enquanto ela aguarda que seus pais a busquem. Apesar destas novas amizades mexerem com os sentimentos da menina, ela permanece aparentemente impenetrável, pois não deseja decepcionar-se mais uma vez com falsas ilusões. No entanto, ela descobre que esse rapaz, chamado Santana, prestes a completar 18 anos, sofre de um câncer e vê que ele, mesmo estando sujeito à morte precoce e iminentemente, luta para viver e aproveitar a vida. Santana também não tem muitos amigos, e os que tem moram longe. Assim, o rapaz comunica-se com eles apenas através do computador, fazendo um uso da mídia radicalmente diferente daquele da protagonista: enquanto Santana usa o ciberespaço para comunicar-se com quem gosta, Daelyn vem tentando efetivar seu suicídio com a orientação do site que acompanha. Ao deparar-se com a experiência de Santana, e também ao observar no site through-the-light que há muitos depoimentos com situações ainda mais estarrecedoras que a dela, a protagonista começa a refletir sob novas perspectivas a questão do suicídio. Apenas no último capítulo do livro podemos saber o que ela realmente decide fazer: viver ou entregar-se à morte?

O site www.through-the-light.com é fictício, porém foi desenvolvido na vida real pela autora do livro em questão para ajudar pessoas que entram nele no intuito de se matarem a reconsiderarem o caso e não fazerem isso. Trata-se de uma idéia muito interessante e que realmente tem potencial para ajudar as pessoas a tomarem a decisão em favor da vida. No site efetivo (não fictício), desenvolvido a partir da obra, podem ser encontrados artigos que explicam o suicídio e o bullying, pesquisas e dados, além de indicar ajuda psicológica para aqueles que passam por alguma dessas situações mencionadas. O livro By the time you read this, I'll be dead, também conta com um guia com este mesmo material em seu final, preocupado em iluminar os jovens leitores a fazerem a coisa certa.

Assim, a obra, acompanhada do site de auto-ajuda, é extremamente relevante para jovens deste mundo de comunicação imediata e veloz através do computador, jovens estes facilmente vulneráveis aos lados sombrios da internet, lados que buscam e alcançam frequentemente por serem vítimas de agressões (físicas ou, no caso de Daely, psicológicas) e não terem aonde buscar entendimento e ajuda. Através da literatura de Petters, esses jovens 
leitores podem ser inspirados a enxergar novas realidades e usar as tecnologias a seu favor como com a página virtual de valorização à vida, desenvolvida fora do âmbito fictício pela autora, e estrategicamente mantendo o mesmo nome do site sombrio da obra literária.

Esta impressionante e dinâmica história fictícia nos mostra como uma pessoa pode ser levada a cometer atos tão radicais como o suicídio levando em consideração como o ciberespaço pode interferir em tal decisão. É interessante destacar os dois lados do site da história: apesar deste ser fictício, o mesmo espaço virtual que busca orientar o ato extremo do suicídio, com seus depoimentos (e outros eventos da vida social da personagem), também faz Daylen refletir sobre sua vida ao observar as tragédias de outros. Visto que a personagem principal já havia tentado suicidar-se mesmo antes de conhecer o site, estando disposta a tentar novamente, e considerando o que ela mesma diz no final da página 85: "I want to tell them, Kim, Chip. Computers don't kill" (em português: "Eu quero dizer para eles, Kim, Chip [seus pais]. Computadores não matam”) podemos inferir que computadores/ciberespaço podem ser caminhos ou fórmulas para realizar coisas, tanto para o bem quando para o lado sombrio, mas não são por si só um fator determinante como o site do livro sugeria ser. A decisão final acaba sempre sendo a do usuário, e no caso de Daelyn, sua escolha foi a de continuar a viver.

\section{Referências}

PETTERS, J. A. By the time you read this, I'll be dead. New York: Hyperion, 2010. 